\title{
CLINICAL EVALUATION OF CERVICOTHORACIC SYMPATHETIC NERVE BLOCK IN THE MANAGEMENT OF BURNS OF THE HANDS*
}

\author{
Stefano Brena, L.D., M.D., Michele BoccA, M.D., AND \\ DaVide Mono, M.D.†
}

IN LESIONS OF THE HAND, the imperative therapeutic object is to obtain not only recovery, but an early and complete recovery such as to avoid scars, painful and vascular disturbances, muscular and joint impairments or dysfunctions. The cardinal factors for proper therapy of injuries of the hand are: ( $i)$ rigorous asepsis, (ii) earliest possible mobilization, (iii) intensive antalgic treatment and maintenance of good circulation in the affected limb, so as to avoid any possible post-traumatic reflex algodysthropy.

A therapeutic programme of this type is required especially for the treatment of burns of the hand. It is known, in fact, that the first consequence of a thermal injury is vasoparalysis and oedema of the injured region. Furthermore, when the burn involves deep epidermal layers, it also affects the pain nerve endings, causing a tumultuous reflex reaction, which locally causes a vasospasm in the marginal zones of the burned area in which vasoparesis has not yet occurfed. A circulatory decompensation occurs, which extends beyond the boundaries of the areas affected by the thermal injury with circulatory stasis in some areas and impaired circulation due to vasospasm in others. The ultimate consequence of this condition is tissue hypoxia, which, in turn, becomes another source of painful stimuli that can aggravate the pain and circulatory decompensation. A vicious circle is thus formed: pain, vasospasm, aggravation of the pain, and vasospasm, which usually gives rise to a greater anatomic injury than that caused by the initial thermal stimulus. ${ }^{1}$ An effective treatment: of pain, therefore, has primary therapeutic importance, being capable not only of relieving the painful symptoms, but also, of rapidly preventing the formation of the above mentioned reflex arc, thus avoiding extension and aggravation of the primary lesion.

Of the many antalgic measures reported in the literature, the most noteworthy seems to be regional nerve block, referred both to somatic sensibility and sympathetic innervation. The observations which are the subject of this paper have preferably turned to this method.

This series includes 140 cases, 70 of which were treated with nerve block, and 70 who received other antalgic treatment. The second group is considered as a control group with respect to the first. Though it was evidently impossible for the lesions to be identical in every case in this series, the patients were selected so as to satisfy a number of requirements.

*Presented at the Second World Congress of Anaesthesiologisists, Toronto, Canada, September 4-10, 1960.

†From the Department of Anaesthesiology and the Department of Plastic Surgery, The Mauriziano Hospital; Turin, Italy.

Can. Anaes. Soc. J., vol. 8, no. 3, May, 1961. 
(1) Extension of burns was never more than the conventional index of 2.5 per cent, corresponding approximately to the hand and forearm.

(2) Depth of lesion was never the conventional limits of the third degree.

(3) First degree lesions were also excluded when, at the time of hospitalization, pain was no longer objectively demonstrable.

(4) Only adult patients were included.
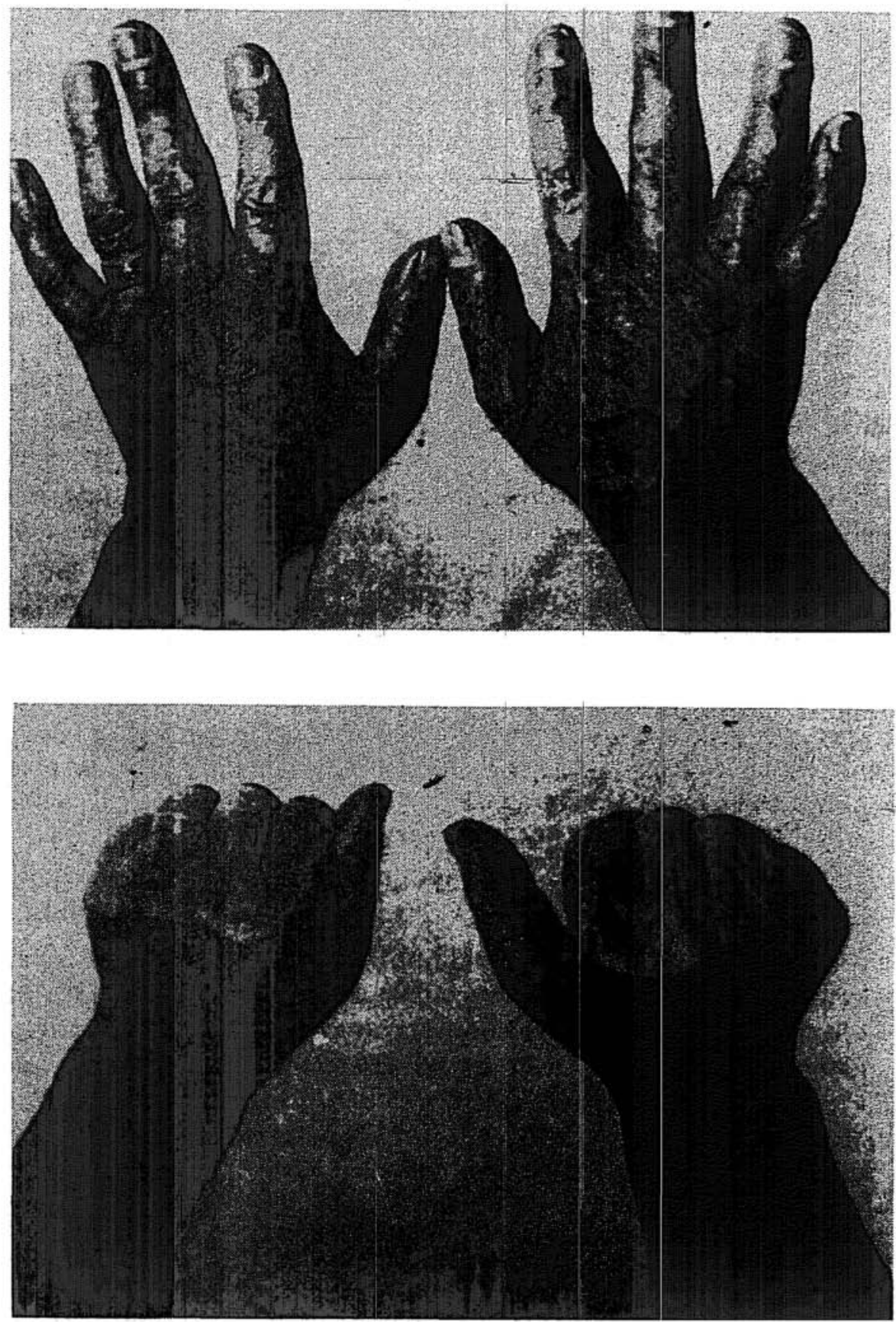

FIGURE 1. Both hands similarly burned. Left side received cervicothoracic sympathetic nerve block. 
(5) All patients who received nerve block treatment, but in whom open treatment of the burn could not be performed according to the standard procedure for the cases examined, were excluded.

Figure 1 shows the case of a patient belonging to both groups of this series. Both upper limbs showed burns of the same extent and severity. However, nerve block was limited to the left arm, and the right arm was used as a control with respect to the left one; in ideal conditions, therefore, for comparative evaluation of 'results, as clearly shown in the figure.

All 140 patients were given the same local and general treatment. Local therapy was as follows: rigorous and extensive disinfection of the marginal tissues of the lesion (burns are aseptic, unless they are contaminated after injury by non-sterile medical dressing or by other factors), free exposure of the burned limb in aseptic surroundings, isolated by means of sterile bandages and towels. The patient was kept in a room containing an ozonizer, and having sufficient relative humidity to avoid raising dust. General therapy consisted lof slow drip infusion of a 5 per cent dextrose plus saline solution in sufficient amount to maintain the salt and water balance in relation to the daily oral fluid intake, to the urinary excretion, and to the amount lost by perspiration. Plasma transfusions were required in a limited number of cáses with more extensive loss of fluid from the injured part.

Nerve block therapy was performed in 70 patients as follows: ${ }^{1}$ upon admission: brachial plexus block via the supra-clavicular approach associated with infiltration of the cervicothoracic sympathetic chain, preferably by the anterior paratracheal approach, using 0.1 per cent pontocaine plus 1/250,000 epinephrine; after 12 hours: a second nerve block, limited to the sympathetic chain; after 24 hours: (when necessary) a third sympathetic block.

The number of infiltrations performed on each patient during hospitalization is shown below.

Total number of infiltrations $\quad 70$

Brachial plus stellate ganglion block 23 (32.8 per cent)

Second stellate ganglion block $\quad 35$ (50 per cent)

Third stellate ganglion block $\quad 12$ (17.1 per cent)

In the remaining 70 patients (control group) antalgic treatment was performed by parenteral administration of narcotic analgesic drugs as follows: pentobarbital $100 \mathrm{mg}$., promethazine $50 \mathrm{mg}$., chlorpromazine $50 \mathrm{mg}$., repeated alternatively every eight hours. In order to evaluate the effectiveness of somatic and sympathetic block for antalgic treatment of burns of the hand, four clinical features will be considered separately, comparing them in the two groups.

\section{Clinical Recovery Time}

Times required for clinical recovery are shown in Table I. In patients receiving antalgic treatment by administration of narcotic analgesic drugs, the average time required for clinical recovery was 14 to 20 days ( 74.2 per cent of cases). This corresponds to the figures reported in the literature: three weeks in Thalheimer's series of second-degree burns;; 15 to 20 days in Viganovi's series of 
TABLE I

Clinical Recovery in 70 Cases

\begin{tabular}{ccc}
\hline & $\begin{array}{c}\text { Patients treated with } \\
\text { nerve block }\end{array}$ & Untreated patients \\
\hline Clnnical recovery & & \\
7 days & $8(114 \%)$ & \\
10 days & $43(614 \%)$ & $13(185 \%)$ \\
14 days & $19(27.1 \%)$ & $25(35 \%)$ \\
20 days & & $27(38) \%)$ \\
Over 20 days & & $5(7.1 \%)$ \\
Complications & & \\
Local & $3(42 \%)$ & $14(42 \%)$ \\
Visceral & & $(20 \%)$ \\
\hline
\end{tabular}

second-degree burns; ${ }^{3} 15$ days in Edouard's series of second-degree burns treated by cryotherapy $;{ }^{4} 14$ to 18 days in the series of Blocker, ${ }^{5}$ Taylor, ${ }^{6}$ and Wallace, ${ }^{7}$ in which open treatment of the lesion was given. Similar observations have also been reported by other authors. ${ }^{8+9}, 10$ On the-other hand, in the group given nerve block treatment, the average time required for clinical recovery was 10 days (61.4 per cent of cases). No reports of more rapid recovery of the seconddegree burns have been found.

\section{Local Complications}

Cicatrization of burns did not differ significantly in the two groups. In the first group, local oedema showed evidence of regression as early as 24 hours after the injury, whereas in the control group regression took place after about 36 or 48 hours, as generally reported in the literature. ${ }^{6,9}$ Reatsefption index was essentially the same in both groups of patients. All the 70 patients given analgesic block treatment were discharged when the lesions were completely re-epithelized, and the hand or the affected joints could be moved with ease, without pain, or vascular or cicatritial impairment. In three cases of the control group (4.2 per cent of cases) it was necessary to cover a granulation in the burned area. According to Rosselli ${ }^{11}$. this plastic procedure should be used routinely in combined second- and third-degree burns, whereas Evans ${ }^{12}$ states that lesions that do not go beyond the papillary state should heal spontaneously when treated with an open aspetic method.

\section{Visceral Complications}

In three of the 70 patients given analgesic block treatment, albuminuria occured on the second day (4.2 per cent of cases). In 14 of the 70 patients of the control group various visceral complications were noted ( 20 per cent of cases): renal block on the third day with recovery on the ninth day (one case); lesion of the bladder mucous membrane observed cystoscopically (one case); albuminuria and microscopic haematuria about the second and third day (12 cases). Body ${ }^{\theta}$ temperature remained more or less unchanged in 125 of the 140 patients. In the remaining 15 cases, all belonging to the control group, pyrexia was observed during the first hours after injury and disappeared about the forty-eighth hour. 


\section{Pain}

Behaviour of the painful symptoms differed in the two groups of patients. Pain was promptly: relieved immediately after brachial plexus block and the absence of painful symptoms persisted for $_{\text {ma }}$ much longer time than might be expected in relation to the anaesthetic potency of the solution used. In reality, a second nerve block was never required before the twelfth hour, and stellate ganglion block alone was sufficient. Furthermore, a second antalgic treatment was required in only 35 of 70 patients ( 50 per cent of cases), whereas a third infiltration was required in only 12 patients (17.1 per cent of cases). It is also interesting to note that psychomotor agitation which is usually present in patients with burns and is generally attributed to a more or less latent shock disappeared as soon as a somatic nerve block was performed, whereas stellate ganglion block sufficed to eliminate residual pain, when present, in the twelfth hour or later. On the contrary, -in the control group, continuous administration of narcotic analgesic drugs every eight hours was refuired. Considerably painful symptoms reappeared in these patients during the first 36 or 48 hours, as soon as the analgesic effect of the injected drug tended to decrease. It should finally be noted that the visceral complications mentioned above appeared in the patients with the severest subjective symptoms, in spite of scrupulous infusion and transfusion therapy.

\section{CONCLUSIONS}

These findings indicate somatic and visceral nerve block can have considerable clinical effects in the treatment of benignant burns of the upper limbs. Its favourable effect seems to affect the time required for healing and the prevention of visceral complications. The effects of this method in the epithellization of the wounds seem less notable, as the types of burns taken into consideration show a good tendency to spontaneous healing, provided that aseptic conditions are maintained in the injured region. In effect, this process seems only accelerated by nerve block as compared with controls and not substantially modified in its anatomic and functional evolution.

Furthermore, nerve block therapy offers marked advantages over a more general antalgic treatment; the physiological injury to the patient by nerve infiltration, with the doses of anaesthetic used, seemed, in fact, by far smaller than the potential dangers of large doses of narcotic analgesic drugs such as are required to relieve the pain of burns of the hand. To underline the importance of this fact, the observations of Elman, ${ }^{13}$ later confirmed by other authors, ${ }^{14}, 15,16$ should be stressed. According to these workers, mortality due to burns seems significantly greater following the administration of large doses of narcotic analgesic drugs. On the contrary, inherent dangers of nerve block the:apy in experienced hands seem negligible. Only two cases of pneumothorax occurred in this series and healed properly without objective or subjective consequences to the patient.

\section{RÉSUMÉ}

Un blocage nerveux somatique et viscéral peut entraîner des effets cliniques salutaires dans le traitement des brûlures bénignes du membre supérieur. Le 
blocage semble produire comme effet adjuvant: une accélération de la guérison et une protection contre les complications. Les effets du blocage sur l'épithélisation des blessures sont moins évidents car les types de brâlures que nous avons étudiés ont montré une tendance spontanée à la guérison, à la condition que l'infection n'envahisse pas la région. De fait, la guérison semble accélérée par le blocage nerveux si l'on fait une comparaison avec des cas témoins et elle ne présente pas de modifications substantielles dans son évolution anatomique et fonctionnelle.

De plus, le blocage nerveux thérapeutique présente des avantages marqués sur un traitement antalgique plus général. Le dérangement physiologiqúe produit chez le malade par l'infiltration, sachant les doses d'agent anesthésique employées, semble, de fait, bien infime comparé aux dangers possibles que pourraient constituer pour le malade de fortes doses d'analgésiques comme on est obligé d'en donner pour soulager les douleurs occasionnées par les brûlures de la main. Pour souligner l'importance de ce fait, nous citons les observations de Elman, ${ }^{13}$ confirmées ultérieurement par d'autres auteurs. ${ }^{14,15,16}$ D'après ces auteurs, le taux de mortalité à la suite de brâlures semble plus élevé si l'on fait usage de fortes doses de médicaments analgésiques. Par contre, dans des mains expérimentées, les risques inhérents au blocage nerveux thérapeutique semblent négligeables. Au cours de cette série, nous avons observé seulement deux cas de pneumothorax et ces deux complications sont demeurées sans conséquence objective ou subjective pour les malades.

\section{REFERENCES}

1. Livingstone, W. K. Pain Mechanisms. New York: Macmillan (1952).

2. Thalhermer, M. Il problema chirurgico delle ustioni: Min. Chir. $9: 5$ (1955).

3. Viganovi, C. Sulla terapia locale delle ustioni. Min. Chir. 20: 1043 (1956).

4. Edouard, V. Un Traitement abortif des brûlures. Progr. Med. 82: 13 (1954).

5. Blocker, T. G. Experience with Exposure Method of Burns Therapy. Plastic Reconstr. Surg. 8: 87 (1951).

6. TAylor, D. G. Exposure Treatment of Burns in Children. Brit. Jour. of Plastic Surg. $5(4): 275$ (1953).

7. Wallace, A. B. Some Experience in Local Care. Brit. Jour. of Plastic Surg. 4 (3): 224 (1951).

8. Imperati, L. Lo stato attuale della terapia delle ustioni. Giorn. Ital. Chir. 2: VIII (1945).

9. Sinigaglia, G. M. Terapia delle ustioni interessanti oltre il 50\% della superficie corporea. Osp. Magg. Milano. 43: 6 (1955).

10. Bergamasco, A. Trattamento delle ustioni con il metodo di Koch modificato. Arch. Ital. Dermatol. 27: 107 (1955).

11. Rosselli, D. Indirizzi ed indicazioni della terapia chirurgica delle ustioni. Arch. Ital. Dermatol. 27: 117 (1956).

12. Evans, A. J. Early Treatment of Burns at a Regional Plastic Centre: A Review of 100 cases Treated by Exposure. Brit. Jour. of Plastic Surg. 5: 263 (1953).

13. Elman, R. In Bonica, The Management of Pain. New York: Lea and Febiger (1953).

14. Perdrup, A. The Treatment of Burns in a Skin Clinic: A 10 Statistical Analysis of 2,201 Cases, with Special Reference to Lethaly and Hẹaling Time of Burns. Acta Chir. Scand. 100 (1): 136 (1950).

15. Miller, H., \& Posh, J. L. Acute Burns of Hands. Amer. Jour. Surg. 80 (6): 784 (1950).

16. Winter, J. J. In Perdrup, A., The Treatment of Burns in a Skin Clinic. Acta Chir. Scand. 100 (1): 136 (1950). 